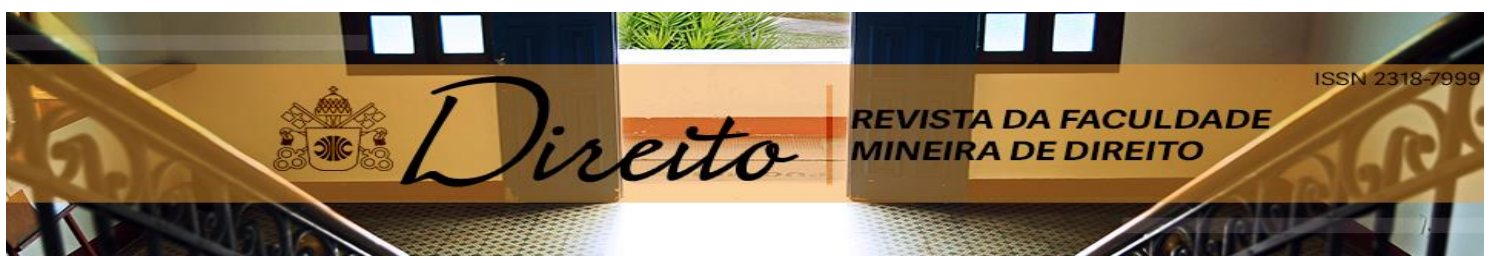

\title{
O SIMBOLISMO NAS SENTENCAS PENAIS CONDENATÓRIA E ABSOLUTÓRIA E O PROCESSO PENAL BRASILEIRO PÓS-CONSTITUIÇÃO FEDERAL DE 1988
}

\author{
SYMBOLISM IN CONDENSATORY AND ABSOLUTE CRIMINAL JUDGMENTS AND \\ THE POST-CONSTITUTIONAL BRAZILIAN PENAL PROCESS OF 1988
}

Fernando Laercio Alves da Silva ${ }^{1}$ Leonardo Augusto Marinho Marques²

\begin{abstract}
Resumo
A promulgação da Constituição Federal de 1988 configurou o compromisso formal do Estado Brasileiro com a submissão de suas estruturas a um novo princípio fundante: o princípio do Estado Democrático de Direito. Essa nova realidade exige a revisitação dos diversos campos de atuação estatal a fim de verificar o grau de sua compatibilização com ela e, sendo o caso, a promoção das reformas necessárias. No que tange ao campo do processo penal, ainda hoje de base inquisitorial, absoluta é sua dissonância da Constituição. Necessário, portanto, um profundo esforço para a remodelação de suas bases a partir do marco teórico processual estabelecido no texto constitucional: o chamado modelo constitucional de processo. Esse esforço deve ser conduzido em três frentes de atuação: a reformulação integral do Código de Processo Penal, a revisitação do papel dos sujeitos processuais e o abandono de termos e conceitos técnicos de origem inquisitorial e cujo uso corrente dificulta a superação dessa mentalidade. Nesse contexto, no presente artigo investiga-se se as expressões sentença condenatória e sentença absolutória encontram-se nesse último grupo e, sendo esse o caso, quais seriam as alterações necessárias para pôr fim ao impacto simbólico que sua manutenção tem ocasionado na realidade processual penal brasileira.
\end{abstract}

Palavras-Chave: Processo Penal. Modelo Constitucional de Processo. Sentenças Condenatória e Absolutória. Significado Simbólico. Inquisitoriedade.

\begin{abstract}
The promulgation of the Brazilian Federal Constitution from 1988 is the official State commitment to submite their structures at a new basic principle: the principle of the Democratic State of Law. This new reality requires the invetigation of all the state activities to verify if they are compatible at the new constitutional order. Wherever that compatibility don't exist, the State need to promote all the necessary reforms. The Brazilian criminal procedure is one of more incompatible state activities at the principle of Democratic State of Law. That's it because the Brazilian criminal procedure is structured in inquisitorial bases. It require a great strategic to rebuild it on the base of the constitutional process model. This effort should be conducted on three fronts: the complete overhaul of the Brazilian Criminal Procedure Code, the remade of the way of working of the criminal procedure subjects and the abandonment of technical terms and concepts originally inquisitorial. In the last case, it's necessary because the use of those terms and concepts difficult the mentality overcome. In this context, in the article it's investigated if the terms conviction and acquittal need to be abandonment. And, if they need to be abandoned, it's necessary to discover the new terms as will be used in their place.
\end{abstract}

Key-words: Criminal Process. Constitutional Process Model. Conviction. Acquittal. Symbolic Meaning. Inquisition.

Artigo recebido em 03 de setembro de 2016 e aprovado em 11 de novembro de 2016 .

1 Doutorando em Direito pela Pontifícia Universidade Católica de Minas. Professor da Universidade Federal de Viçosa, Viçosa, Minas Gerais, Brasil.

2 Doutor em Direito pela Pontifícia Universidade Católica de Minas. Professor da Pontifícia Universidade Católica de Minas Gerais, Belo Horizonte, Minas Gerais, Brasil. 


\section{INTRODUÇÃO}

\section{Apresentando o problema: as expressões sentença condenatória e sentença absolutória como resquícios de um processo de base inquisitorial}

O estudo e a pesquisa a partir da perspectiva popperiana (POPPER, 2009) tem como traço elementar o questionamento exige que jamais nos contentemos em simplesmente acolher uma técnica ou mesmo uma teoria - qualquer que seja a sua natureza - sem previamente submetê-la ao crivo da crítica, isto é, sem interroga-la em seus aspectos fundamentais. Isso porque, somente enquanto respondidas adequadamente às interrogações da crítica, é que tanto a técnica como a teoria poderão ser reputadas válidas. Por outro lado, a sucumbência à crítica é que move o avanço científico (LEAL, 2012, p. 38), pois resulta, nas palavras de Popper, na "eterna mutação" das teoria científicas (2009, p. 74).

A metodologia de pesquisa popperiana, como já esclarecido em diversos ensaios e obras por Rosemiro Pereira Leal (2012; 2013), se mostra perfeitamente adequada à pesquisa nos mais diversos campos da ciência jurídica - inclusive no campo do direito processual penal e, por essa razão, dela nos valemos para o levantamento da interrogação crítica que intitula o presente trabalho.

Esclarecido esse ponto, cumpre-nos desde já passar ao enfrentamento da questão apresentada no título do trabalho, qual seja, se o simbolismo presente nas expressões sentença condenatória e sentença absolutória, há muito enraizadas na tradição processual penal brasileira, se compatibiliza com o modelo constitucional de processo, marco teórico ao qual se filiou o Brasil a partir da Constituição Federal de 1988 e às perspectiva do direito processual penal do fato, e não do autor.

Tal questionamento poderia, para o leitor mais desavisado, passar por mera frivolidade ou filigrana jurídico. Enfim, uma discussão de pouca relevância teórica e prática, ainda mais se considerado o cenário de grandes turbulências jurídico-econômico-sociais do Brasil atual. Qual a importância em se pôr em xeque duas expressões há tempos consagradas tanto na legislação ${ }^{1}$ como na práxis processual penal. O uso consagrado de tal técnica redacional para a identificação dos conteúdos das decisões processuais penais de mérito proferidas na primeira instância, contudo, não é impeditivo de sua crítica. Ao contrário, exatamente por se tratar de uma técnica há muito enraizada na literatura processual penal, é que sua submissão a um processo de refutabilidade se faz necessária a fim de se verificar a persistência de sua adequação teórica. Como esclarece Fernanda Gomes e Souza Borges, "todo enunciado e toda teoria devem ser

\footnotetext{
${ }^{1}$ Em rápido exercício, verificamos que o Código de Processo Penal brasileiro, vigente desde 1941, utiliza a expressão sentença condenatória em 23 ocasiões - nos artigos 63; 63, parágrafo único; 68; 122; 130, parágrafo único; $133 ; 135, \S 5^{\circ} ; 143 ; 283 ; 334 ; 336$, parágrafo único; 373, IV; 374, II e II; 377; 385; 530G; 597; 621, I e II; 625, § 1º ; e 629 - e a expressão sentença absolutória em outras 07 ocasiões - nos artigos 66; 67, III; 81; 337; 378, III; 386, caput e parágrafo único. E isso sem se levar em conta outras tantas menções a tais expressões entre os artigos 673 a 811, tacitamente revogados pela Lei n. 7.210/1984, conhecida como Lei de Execução Penal.
} 
submetidos a testes ou, pelo menos, serem suscetíveis de refutação, pelo falseamento de algumas das conclusões que deles possam ser deduzidas" (2013, p. 27).

Por essa razão é que a submissão das expressões sentença condenatória e sentença absolutória ao crivo da refutabilidade científica se mostra absolutamente necessária, tanto do ponto de vista teórico, como por conta dos impactos simbólicos que delas decorrem. E, para que a investigação se desenvolva de maneira eficiente, primeiramente enfrentaremos a questão da correta conceituação da expressão sentença e, somente em um segundo momento, das expressões condenatória e absolutória, utilizadas como adjetivos indicadores do conteúdo decisório da sentença. Isso porque, somente após esclarecido aquela expressão é que se consegue compreender o sentido e a abrangência dessas.

O ponto de partida não poderia ser outro que não o texto do Código de Processo Penal atualmente em vigor no Brasil, o qual, no Título XII de seu Livro I tem por objeto exatamente a disciplina normativa do instituto da sentença penal. Nota-se, a partir da leitura dos artigos contidos no mencionado título, que o legislador jamais se preocupou não se preocupou - nem à época da edição do decreto-lei n. 3.689/1941 e nem posteriormente, não obstante as diversas alterações legislativas sofridas pelo CPP ao longo de seus setenta e cinco anos de vigência -, com a fixação de um conceito legal de sentença.

Semelhante silêncio legislativo, que se percebe no texto do Código de Processo Civil de 1939, editado no mesmo período e sob a mesma mentalidade do Código de Processo Penal, não se repetiu nos textos legislativos que o sucederam, quais sejam, tanto o Código de Processo Civil de 1973, como o Código de Processo Civil de 2015, este último o atualmente em vigor². Em ambos os diplomas legais, a sentença é conceituada como "o pronunciamento por meio do qual o juiz [...] põe fim à fase cognitiva do procedimento comum, bem como extingue a execução" (BRASIL, 2015) ${ }^{3}$.

Não obstante o silêncio normativo, o conceito de sentença para o processo penal, em sua essência, nada se distingue do processo civil. Também aqui a sentença é o pronunciamento por meio do qual, após o regular trâmite procedimental e asseguradas concretamente as garantias constitucionais do processo, o juiz decide a lide e, assim, põe fim à fase cognitiva do processo. Nesse sentido, Nereu Giacomolli ensina que a sentença "[...] se constitui no ato processual por excelência na esfera criminal, na medida em que põe fim ao processo, ainda que não necessariamente de modo definitivo, pois existe a possibilidade de a decisão ser modificada, negando ou confirmando o estado de inocência" (2014, p. 222).

$\mathrm{E}$, pôr fim ao processo significa, no processo penal, decidir o mérito do pedido inicialmente formulado pelo órgão de acusação por meio da denúncia - quando se tratar de ação

\footnotetext{
${ }^{2} \mathrm{O}$ conceito legal da sentença para o processo civil encontra-se previsto no art. $203, \S 1^{\circ}$ da Lei n. 13105/2015, o Código de Processo Civil atualmente em vigor. Anteriormente, ainda na vigência do Código de Processo Civil de 1973 - Lei n. 5.869/1973, o conceito legal de sentença encontrava-se estampado em seu art. $162, \S 1^{\circ}$.

${ }^{3}$ A título de esclarecimento, vale mencionar que Alexandre Antônio Franco Freitas Câmara, conceitua o verbete sentença de maneira ainda mais clara o ordenamento legal, sustentando que "sentença é o ato do juiz que põe fim ao seu ofício de julgar, resolvendo ou não o mérito da causa. Se se preferir, adotando-se uma terminologia que nos parece adequada ao atual sistema do CPC, sentença é o ato do juiz que põe fim a um módulo processual, resolvendo ou não o mérito da causa" (2007, p. 447)
} 
penal pública - ou queixa-crime - quando for o caso de ação penal privada. Quanto a esse ponto, acreditamos não haver dúvida, já que - ao menos aqui - o legislador foi cuidadoso - mais até que no processo civil - e somente utilizou o termo sentença para se referir à decisão judicial proferida pelo juízo de primeira instância, seja o juízo monocrático, seja o presidente do Tribunal do Júri, para decidir o mérito da causa e, assim, pôr termo ao processo 4 .

A questão, entretanto, não é tão simples. Quando aprofundamos no estudo da sentença penal, salta aos olhos o fato de que ela ainda é concebida e trabalhada não a partir de fundamentos de uma racionalidade processual-democrática, mas sim em elementos metajurídicos - por vezes até mesmo sensitivos - voltados à busca de uma suposta verdade material que há muito já foi abandonada pela filosofia do direito (SAMPAIO, 2010).

Oferecidas as alegações finais orais ou por memorais, não importa, o juiz é chamado a proferir o ato derradeiro de todo e qualquer processo: a sentença.

Sentença, assim, vem do latim sententia, que se origina de sentiendo, gerúndio do verbo sentire, ou seja, onde o juiz exprime aquilo que ele está sentindo. (RANGEL, 2012, p. 574).

Decidir a lide penal, no final das contas, acaba não passando de um ato de fé, um decisionismo subjetivista do julgador (MARQUES, 2012, p. 159). O que deveria ser um exercício técnico de testificação/refutabilidade dos argumentos sobre os quais se foi lançada a hipótese acusatória e o condenatório, acaba se limitando à experiência e à sensibilidade do juiz que, nas palavras de Rosemiro Pereira Leal, se comporta como "um achador (descobridor) de um preceito ético diluído na névoa dos tempos só sensilizável por um sentire divinatório do descobridor da sentença (Unteilsfinder)" (2002, p. 19).

E a questão ainda se agrava com a inclusão dos adjetivos condenatória e absolutória como formas de identificação do conteúdo meritório do texto decisório. Inclusão essa que, salvo melhor juízo, ainda não fora devidamente questionada academicamente, persistindo tanto no corpo do ordenamento legal como nas inúmeras obras jurídicas destinadas a sua análise sem despertar maiores atenções.

\section{Denuncia Geraldo Prado que}

Manuais jurídicos e textos que circulam na web servem ao propósito de adestrar tecnicamente profissionais e futuros profissionais do Direito e estes mesmos manuais parecem impermeáveis às críticas dirigidas à idoneidade das categorias principais com as quais trabalham. Não raro mesmo os tribunais reproduzem os termos míticos falaciosos do Direito como se estes fossem verdades sacralizadas, sem enrubescimento ou mesmo indício de que percebem a escassa densidade científica do que é afirmado como justificativa para as decisões". (PRADO, 2012, p. 27).

Perceba o leitor que essa reprodução acrítica, no que diz respeito às expressões sentença condenatória e sentença absolutória aqui investigadas, remonta períodos mais distantes da história processual penal brasileira. Somente a título de exemplo nesse sentido convém lembrar que há mais de um século, Galdino Siqueira já o fazia ao apresentar os conceitos técnicos de sentença absolutória e sentença condenatória no então vigente Código de Processo Criminal brasileiro, dizendo que

\footnotetext{
${ }^{4}$ Como já esclarecido por Giacomolli, o juiz põe termo ao processo por meio da sentença na medida em que, por meio dela, encerra a cognição processual em primeira instância e, salvo nos casos de recurso interposto por qualquer das partes, seu trânsito em julgado formará coisa julgada.
} 
A sentença subdivide-se em absolutoria e condemnatoria.

E' absolutoria quando o jury nega a existencia do facto principal, ou quando afirmando-o, reconhece qualquer das excusas ou justificativas previstas em lei. [...]

A sentença é condemnatoria quando o jury afirma os factos da acusação e nega os de defesa concernente á isenção penal. (sic). (SIQUEIRA, 1910, p. 499).

A partir dos conceitos apresentados por Galdino Siqueira, a expressão sentença condenatória identificaria $\mathrm{o}$ ato decisório de mérito proferido pelo juiz criminal que acolhe 0 pedido condenatório por aceitar como verdadeiro os fatos da acusação e, como falsos os da defesa. Por sua vez, a sentença seria absolutória quando negasse a existência do fato da acusação ou, mesmo existente tal fato, reconhecesse também a presença de alguma das excludentes (de tipicidade, ilicitude ou culpabilidade, em uma leitura mais atualizada das excludentes do crime) (BITTENCOURT, 2008).

O problema é que as expressões condenação e absolvição guardam em si uma carga histórico-simbólica muito mais pesada do que faz parecer a singela explicação de Galdino Siqueira. Remonta ao sistema inquisitivo romano-canônico, no qual o juiz "passa a ser o órgão responsável pela procura e punição dos 'inimigos ocultos'" e o "imputado, considerado herege já no início da persecução [...] era o ser humano, o portador do 'pecado original' e, exatamente por portá-lo, sempre passível de um mal emergente ao mínimo descuido" (MORAES, 2010, p. 53).

Pela lógica da inquisitoriedade, como o homem já nasceria culpado, bastaria escavar em um ponto qualquer - no caso, o crime do qual se visse acusado - para que mal aflorasse (CORDERO, 1993, p. 24). Também por essa lógica, o ato de se condenar o acusado não passaria do reconhecimento de seu status de pecador em uma dada situação concreta. Por outro lado, o ato de se absolve-lo não significaria o reconhecimento de sua inocência - mesmo porque, à exceção do Criador e de seu Filho, ninguém seria inocente -, mas apenas que o órgão de acusação não teria escavado o suficiente (MORAES, 2010, p. 55).

Em verdade, as próprias expressões condenação e absolvição, aplicadas de maneira tão corriqueira no Direito Processual Penal atual, tem origem com o Direito Canônico, a tradição eclesiástica e os próprios dogmas e sacramentos básicos do cristianismo. A condenação, como já esclarecido, estaria ligada à natureza pecadora do ser humano, desde seu nascimento - ou mesmo antes dele - já condenado pelo pecado original, enquanto a absolvição adviria da graça divina pelo sacrifício de Cristo e em favor daqueles que se arrependessem de seus pecados (AGOSTINHO, 1998). Com base nesses conceitos é que, inclusive, durante a inquisitoriedade havia duas modalidades distintas de sentença absolutória, uma primeira em razão da comprovação de ausência de culpa (inocência) do acusado, da qual não lhe resultava qualquer reprimenda; e uma segunda, a absolvição de instância, que ainda implicava na submissão do acusado - absolvido - a purgar "eventuais indícios ou presunções que contra ele tivessem ou, em certos casos cuja prova era mais tênue, [...] a assumir as custas e pagar fiança para que fosse liberado do cárcere, retomando sua liberdade" (GIL, 2003, p. 83).

É óbvio que há muito o Direito Canônico e a Doutrina da Igreja perderam seu espaço como fontes formais do Direito Processual Penal. Não obstante isso, as expressões condenação 
e abso/vição, ainda hoje utilizadas como adjetivos indicadores do conteúdo da sentença penal, persistem como resquícios da mentalidade inquisitória, com forte reflexo simbólico sobre o acusado.

Perceba o leitor o que estamos a dizer: embora o objeto de análise do processo penal seja a hipótese acusatória lançada na denúncia ou queixa - a despeito de, tecnicamente, o que estar em discussão e, portanto, sob o juízo de validação/refutabilidade, seja o pedido da acusação e os argumentos que o sustentam -, o uso dos adjetivoadores condenatória e absolutória na sentença penal simboliza um ato - real ou imaginário - do julgador de voltar seus olhos para a pessoa do acusado, condenando ou absolvendo- $0^{5}$. Com isso, mesmo que o resultado no campo técnico-procedimental seja o mesmo - condenar o acusado significando acolher a hipótese acusatória e absolve-lo, refutá-la - o efeito simbólico da linguagem é sobremaneira impactante.

As formalidades do campo jurídico, que se expressam não apenas nas encenações ritualísticas, mas também - e arriscamos dizer especialmente na linguagem, é também um viés do exercício de poder. Como no ritual litúrgico religioso, os presentes devem receber o juiz em pé, sentar-se assim que liberados pela autoridade máxima. Como no ritual religioso, a linguagem é um instrumento do poder simbólico: só quem está autorizado e legitimado para proferir a fórmula condeno capaz de produzir efeitos no mundo e, portanto, com uma existência de eficácia performativa é o juiz de direito presidente do processo, assim como o padre (ou pastor, ou qualquer autoridade religiosa) quando declara marido e mulher em uma celebração de casamento, conferindo oficialmente as bênçãos de Deus. (BITTENCOURT, 2012, p. 03).

Em síntese, o juiz, ao proferir as sentenças condenatória e absolutória, embora em concreto esteja decidindo se acolhe ou não a pretensão acusatória, simbolicamente está - na mais absoluta manifestação de Poder (FOUCAULT) - declarando a culpa ou a inocência (ou ausência de culpa) do acusado.

\section{O modelo constitucional de processo, aderido pelo Brasil a partir da Constituição Federal de 1988 e a necessária revisitação dos termos e expressões empregados no processo penal}

Rosemiro Pereira Leal ensina que no direito democrático, a validade e a eficácia das decisões expedidas se alcança e demonstra "pelo teor conteudístico de suas características discursivas de compatibilidade teórica com o modelo constitucional de Estado (marco teóricoparadigmático) em que são produzidas" (2002, p. 121). Modelo constitucional que, nas palavras de Ronaldo Brêtas de Carvalho Dias, nada mais é que "a metodologia normativa que, em grau máximo, informa e orienta o processo jurisdicional, o processo legislativo e o processo administrativo" (2015, p. 41) e, segundo André Luis Del Negri, seria a "instituição regenciadora

\footnotetext{
${ }^{5}$ Note o leitor, inclusive, que a impropriedade técnica da expressão é gritante: se na tradição e nos dogmas da Igreja a absolvição requer prévio reconhecimento de culpa do pecador - que o faz perante o sacerdote durante o rito do sacramento da Penitência -, não poderia ser empregado para identificar a ausência de culpa do indivíduo. Nesse sentido, é o que estabelece o Catecismo da Igreja Católica: "Aqueles que se aproximam do sacramento da Penitência obtêm da misericórdia de Deus o perdão da ofensa a Ele feita e, ao mesmo tempo, são reconciliados com a Igreja, que tinham ferido com o seu pecado, a qual, pela caridade, exemplo e oração, trabalha pela sua conversão" (VATICANO, 1993, p. 391).
} 
de todo e qualquer procedimento (devido processo legal), a fim de tutelar os provimentos, seja administrativo, legislativo ou judicial" (2008, p. 118).

Ora, se o Estado Brasileiro, a partir da promulgação da Constituição Federal de 1988, se autoproclama um Estado Democrático de Direito - em que pese se tratar de um Estado Democrático de Direito ainda em desenvolvimento (BRÊTAS, 2015), inevitavelmente todo ato decisório que venha a ser dele emanado somente alcançará validade e legitimidade se construído de maneira processualizada ${ }^{6}$ e com absoluta atenção ao princípios que definem o processo como garantia do cidadão (BARROS, 2008, p. 15).

No que diz respeito especificamente ao processo penal, a submissão tanto da estrutura normativa com base na qual concretamente se desenvolvem as atividades de investigação, acusação e decisão ao marco teórico do modelo constitucional de processo, como do próprio comportamento dos sujeitos processuais no desempenho dessas atividades, implica na revisitação e reconstrução de seus elementos a partir da "[...] base principiológica uníssona, consolidada pelo contraditório, ampla argumentação, fundamentação da decisão e o terceiro imparcial [...] sem se desconsiderar o princípio constitucional da presunção de inocência e a garantia das liberdades individuais dos sujeitos" (BARROS, 2008, p. 15).

Uma das mais urgentes mudanças comportamentais para a concretização giro estrutural do processo penal, que leva ao efetivo abandono da herança inquisitorial e à sua reconstrução sob o horizonte interpretativo da Constituição Federal de 1988, consiste na eliminação do que se poderia chamar de antropocentrismo processual. Ainda hoje o acusado persiste colocado no local de mero objeto da investigação e do processo, exatamente no centro das atividades acusadora e julgadora. Exibido como troféu perante os veículos midiáticos pelos órgãos de investigação e persecução penal, desde a etapa das investigações policiais até o momento derradeiro da sentença, o olhar processual se direciona para a pessoa do acusado, e não para o texto da peça acusatória.

Daí falarmos em necessidade de eliminação de um antropocentrismo processual, imperante no processo desde os tempos mais remotos. Indispensável se faz, para a efetiva reconstrução do processo penal brasileiro a partir do modelo constitucional de processo, que o que está sob julgamento - e portanto, no centro processual - não é a pessoa do acusado (a fim de que seja declarado condenado ou absolvido), mas sim a hipótese acusatória, enfim, o pedido de aplicação de pena pelo órgão acusador e os argumentos jurídicos com base nos quais tal pedido é formulado.

$\mathrm{Na}$ esteira do pensamento de Salo de Carvalho

Com a verificação de que o pressuposto do processo penal democrático é a sistematização desde o sistema acusatório, as regras processuais relativas à investigação, aos pressupostos e às condições da ação, à competência, à produção e à refutabilidade das provas, ao procedimento, aos requisitos e aos elementos da sentença penal, aos critérios para recorribilidade e à forma de execução constituem-se

\footnotetext{
${ }^{6}$ A expressão é aqui utilizada em conformidade com a perspectiva fazzalariana, segundo a qual o processo é concebido como procedimento, uma sequência de normas, atos e posições subjetivas voltadas à construção do provimento, no qual é garantida a efetiva participação dos atingidos pelo provimento com real possibilidade de influência para o resultado desse provimento (FAZZALARI, 1996, p. 82)
} 
como barreiras de contenção ao transbordar punitivo. Exatamente pela tendência dos sistemas punitivos em se aproximar da estrutura inquisitória, efetivando sua forma mais pura e revelando seu desejo mais íntimo: a vontade de punição.

Neste sentido, a harmonização dos sistemas de garantias com os postulados dos direitos humanos impõe radical inversão da lógica inquisitorial, qual seja, em decorrência de as regras formais serem normas de garantia, sua flexibilização ou ruptura, por si só, indicaria a nulidade, cabendo ao órgão acusador a demonstração da não causação do prejuízo e o consentimento da defesa para que haja sua convalidação. (CARVALHO, 2013, p. 167).

Nessa empreitada de superação do antropocentrismo processual e de implementação do modelo constitucional de processo no âmbito do processo penal, três linhas de frente, a nosso ver, devem ser desbravadas: a reestruturação dos procedimentos, que, por óbvio, somente pode ser implementada por meio de um sério e profundo processo de reforma legislativa ${ }^{7}$; de uma radical mudança de postura dos sujeitos processuais, por meio da qual o magistrado se assuma efetivamente como terceiro imparcial - e não um agente de segurança pública do Estado - o ministério público, como parte - e não como uma esquizofrênica parte imparcial - e o defensor como sujeito debatedor - e não apenas um ouvinte passivo e um caçador de nulidades processuais; e, por fim, mas não menos importante, do abandono das fórmulas e termos cujos significados remetem a um modelo inquisitorial de processo, sem o que dificilmente os vícios comportamentais cimentados ao longo de séculos de práxis serão superados.

Há mais de trinta anos, Lola Aniyar de Castro já alertava para as consequências desse etiquetamento do indivíduo por meio de expressões e termos de uso corrente no direito e no processo penal, esclarecendo que

As etiquetas dirigem a atividade social: ao se reduzirem as ambiguidades ( $\mathrm{sic}$ ) pelo processo unitário de identificação que representa a colocação de uma etiqueta, também a audiência social se encontra em um corredor que a dirige para uma conduta reativa, enérgica e solidária". A comunidade se une ao ter uma apreciação que é comum a todos os integrantes e por isso se mobiliza para atuar. As etiquetas [...] ex-condenado e viciado em drogas, por exemplo, incitam e mobilizam a energia pública. Por isso se diz que a etiqueta é uma profecia auto-realizável (sic). (CASTRO, 1993, p. 14).

No mesmo sentido, Christina Aguiar et ali esclarecem que

Assim, para além da técnica judicial, é possível que exista uma tendência, pré-formada, de concepção subjetiva, internalizada de alguma maneira no processo de formação do sujeito, que apareça no momento da decisão judicial? Esta indagação também direciona a reflexão para o tipo de sujeito para à qual se destina a decisão (aqui o réu o adolescente autor de infracional, ou, como símbolo linguístico, simplesmente "delinquente"), pois os sentidos humanos permitem defesas automáticas que nos dão os sinais de ameaça. Desta forma, a visão e a oralidade transformam-se em mecanismos de ação sobre o "outro", seja na medida em que o "avalio" pela aparência", seja quando eu o "julgo" por palavras. (AGUIAR, 2013, p. 02).

\footnotetext{
${ }^{7}$ Nesse contexto, convém esclarecer o leitor de que, até o fechamento do presente ensaio, o Projeto de Novo Código de Processo Penal brasileiro, cuja tramitação se iniciou no Senado Federal no ano de 2009, ainda se encontra pendente de aprovação na Câmara dos Deputados (onde tramita sob a numeração de PL $\mathrm{n}$. 8.045/2010). Convém esclarecer ainda que a versão atualmente em análise na mencionada Casa Legislativa muito se modificou em relação ao texto originalmente construído a partir da comissão de juristas constituída pelo Ministério da Justiça ainda na primeira década deste Século XXI e que, a nosso ver, o conjunto de emendas parlamentares voltadas a novas alterações do projeto de lei tende a desnaturá-lo completamente.
} 
São exatamente as consequências desse etiquetamento que se precisa afastar para a efetiva estruturação do processo penal brasileiro sobre a base principiológica constitucional seja porque, em um primeiro momento, ele exerce efeito imunizante sobre as garantias constitucionais processuais do acusado, em especial as da ampla defesa e da presunção de inocência enquanto norma probatória e norma de juízo (MORAES, 2010); seja porque, em um segundo momento, estende as consequências sociais do processo para além do tempo de sua duração e de maneira quase tão danosa quanto a própria sanção penal acaso aplicada ${ }^{8}$.

Obviamente o abandono dos termos condenatória e absolutória, bem como de todos aqueles que, embora de uso corrente na prática processual penal nem de longe seria suficiente à transmutação deste de um processo de base inquisitorial - ou neoinquisitorial (LOPES JR, 2005) - em um processo adequado aos ditames do modelo constitucional. Por outro lado - e é isso o que queremos esclarecer neste breve ensaio -, a ausência de preocupação com a persistência dessas expressões, incompatíveis com o projeto de processo penal estabelecido na Constituição Federal de 1988, acaba dificultando a concretização desse projeto na medida em que a mentalidade inquisitorial não é atacada nos pequenos detalhes.

\section{Como bem esclarece Luis Gustavo Grandinetti Castanho de Carvalho}

É inegável que o cérebro cruza informações para bem funcionar. Para pensar, une-se a memória (passado) à percepção (presente) para projetar o futuro. O pensamento constitui a busca de algo que a pessoa queira ou necessite e expressa imensa vontade de criar. Normalmente, a consciência está envolvida no ato de pensar e de julgar, mas, como julgamos inúmeras questões ao longo do dia, muitas vezes, a consciência não está presente em todos os momentos. A consciência não é sempre necessária para discriminar, decidir, julgar questões de menor importância. Julgamos, muitas vezes, automaticamente.

O julgamento judicial não é um modo estruturalmente diferente de usar o cérebro. Do mesmo modo que os hemisférios do córtex se comunicam, que as habilidades de cada hemisfério se completam, também o processo decisório judicial é rico em comunicações e percepções, vindas da Constituição, da lei, da jurisprudência, da prova dos autos, das máximas da experiência, das influências externas de ordens variadas (políticas, econômicas, sociais) etc.

Igualmente, o processo decisório judicial pode abstrair-se, em maior ou menor medida, da consciência, quando o inconsciente se interpõe. Ou pode automatizar-se tanto que obnubile vontade criativa que é a nota essencial do pensamento. (2012, p. 89).

É nesse sentido que a substituição das expressões sentença condenatória e sentença absolutória, no processo penal, em razão de toda a carga simbólica e estigmatizante, capaz, muitas vezes, tanto de automatizar o ato de julgar como de criar falsas conclusões sociais a respeito do acusado, se mostra medida urgente.

\footnotetext{
${ }^{8}$ Um pequeno, porém importante, passo foi dado nesse sentido quando da edição das Leis n. 11.719/2008 e 12.403/2011, as quais, entre tantas outras alterações no corpo do CPP, levaram à substituição da expressão réu por acusado em vários dispositivos legais, entre os quais os artigos 289, 341, 344 e 345, alterados pela Lei n. 12.403/2011, e os artigos 396 e 396-A, alterados pela Lei n. 11.719/2008.
} 


\section{O antigo, porém ainda não observado, exemplo do processo civil: a sentença somente pode ser de procedência ou improcedência do pedido}

O estudo da teoria geral do processo, da teoria geral do processo civil e, mais especificamente, do instituto da sentença no direito processual civil, nos permite alcançar algumas conclusões.

A primeira delas é que, aquilo que no processo penal tornou-se tradição, que é a identificação das sentenças de mérito como condenatória ou absolutória - e, principalmente, o o uso, em letras garrafais e negritadas no corpo do dispositivo decisório, dos termos condeno $o$ acusado (ou réu) ou absolvo o acusado (ou réu), não se verifica no processo civil. Ao contrário, no processo civil as sentenças, até mesmo por expressa determinação legal, em seu dispositivo, devem estabelecer se julgam ou não procedente o pedido formulado à petição inicial (ou na reconvenção, instituto específico daquele campo processual). Nesse sentido, o Código de Processo Civil de 1973 já dispunha em seu art. 459 "o juiz proferirá a sentença, acolhendo ou rejeitando, no todo ou em parte, o pedido formulado pelo autor".

Comentando o dispositivo legal, Marcos Afonso Borges esclarece que "[...] o diretor do processo proferirá sentença: a) acolhendo o pedido (procedente); b) acolhendo em parte o mencionado pedido (procedente em parte); e c) rejeitando-o 'in totum' (improcedente)" (1975, p. 140). No mesmo sentido, e com a síntese que Ihe é peculiar, Moacyr Amaral Santos, tratando do mesmo dispositivo, ensina que as sentenças definitivas "são aquelas que decidem o mérito da ação, isto é, decidem do pedido, da pretensão deduzida pelo autor, acolhendo-a ou rejeitandoa" (2004, p. 286).

Em 2015, como é de conhecimento público, entrou em vigor o novo Código de Processo Civil brasileiro. Não obstante as inúmeras inovações tanto no campo técnico como no teórico que foram implementadas no corpo desse novo diploma legislativo, a regra originalmente estampada no caput do art. 459 do CPC de 1973 fora, em sua essência, reprisada no texto do no Código, apenas cindida e remanejada para o seu art. 487, I, que estabelece: "haverá resolução de mérito quando o juiz: I- acolher ou rejeitar o pedido formulado na ação ou reconvenção". Com isso, o foco do juiz civil é mantido exatamente onde ele deve estar: na análise criteriosa dos argumentos e pedidos formulados pelo demandante, e não na pessoa do demandado.

A segunda conclusão possível, a partir do aprofundamento no conhecimento do processo civil, é o de que aquilo que se pretende, no processo penal, pelo uso dos termos condenatória e absolutória no processo civil é realizado de maneira não apenas mais simples, mas também mais técnica e livre de impactos simbólicos. Nota-se uma grande preocupação dos processualistas civis com o esclarecimento dos efeitos possíveis de ser conferidos à sentença conforme julguem ou não procedente o pedido e conforme o tipo de pedido formulado. Assim, não as sentenças, mas os efeitos da sentença podem ser classificados em condenatório, constitutivo e declaratório, cujos conceitos aqui apresentados são extraídos da obra de Leonardo Greco em razão de sua precisão técnica.

O efeito declaratório é inerente às sentenças de mérito, que são aquelas que traduzem um juízo de certeza sobre a existência do direito do autor ao bem da vida que é objeto do pedido [...] as sentenças declaratórias podem limitar-se a reconhecer a existência ou 
inexistência de uma relação jurídica, a autenticidade ou falsidade de um documento [...].

A sentença com efeito constitutivo caracteriza-se por criar, modificar ou extinguir uma relação ou situação jurídica. Logo, a sentença constitutiva altera o direito das partes que, antes dela, era um e, em decorrência dela, passa a ser outro [...].

O efeito condenatório da sentença acrescenta ao efeito declaratório a imposição de uma prestação de uma das partes, normalmente o réu, em benefício da outra. (2011, p.278-279).

Perceba o leitor que, de fato, aquilo que o processo penal trabalha como modalidades de sentença, lançando um nefasto efeito simbólico sobre o acusado, o processo civil considera, de maneira mais técnica, a nosso ver, simplesmente como efeitos da sentença de mérito. Nesse sentido, a absolvição do acusado nada mais seria que a manifestação do efeito declaratório da sentença meritória que julga improcedente o pedido formulado pela acusação e, assim, conserva intacta a presunção de inocência do acusado - que já lhe pertencia desde antes do início do processo e que somente poderia ser afastada caso o pedido tivesse sido julgado procedente (MORAES, 2010). Por sua vez, a condenação do mesmo acusado não passa da manifestação dos efeitos constitutivo - que cria uma nova situação jurídica, transformando o acusado de presumido inocente em culpado - e condenatório, consistente este último na fixação de uma pena privativa de liberdade, restritiva de direitos e/ou de multa.

Não seria isso, então, a mesma coisa? A nosso ver, não! A preocupação que buscamos externar ao longo desse breve ensaio não é tanto com o resultado do processo, mas sim como as terminologias empregadas para identificar tal resultado, demonstrando que a persistência acrítica de expressões originárias no modelo inquisitorial de processo pode dar causa a efeitos simbólicos que não se compatibilizam com o marco teórico processual inaugurado no Brasil em 1988. Expressões essas que não são encontradas no processo civil - e ainda que porventura utilizadas, o são desprovidas da carga simbólica presente no processo penal. Afinal, mesmo que o processo civil tenha servido como - e para alguns ainda tenha o papel de ser - instrumento de pacificação social ${ }^{9}$, jamais foi estruturado, como o processo penal, como instrumento de segurança pública.

É exatamente essa visão que ainda se tem do processo penal brasileiro - de que se trataria de um instrumento de segurança pública - é que precisa ser urgentemente afastada. No Estado Democrático de Direito, processo não é instrumento do Estado, mas sim garantia do cidadão (BARROS, 2008). E, sendo o processo, inclusive o penal, uma garantia do cidadão, não pode se valer de expressões de cunho simbólico já que, além disso caracterizar um contrassenso, se mostra capaz de comprometer o cumprimento de seu objetivo.

Por essa razão é que, a nosso ver, o uso das expressões sentença condenatória e sentença absolutória deve ser abandonado no processo penal brasileiro. Em seu lugar, basta a

\footnotetext{
${ }^{9}$ Não obstante discordemos veementemente do pensamento da chamada Escola Instrumentalista do Processo, capitaneada por Cândido Rangel Dinamarco, por considera-lo incompatível com as exigências do Estado Democrático de Direito e com o modelo constitucional de processo, este não é o melhor lugar para rebate-la, deixando tal tarefa para outra ocasião. Por hora, apenas indicamos ao leitor algumas das obras nas quais a temática é trabalhada de maneira aprofundada, em especial, os escritos de Ronaldo Brêtas de Carvalho Dias, Rosemiro Pereira Leal e André Luis Del Negri.
} 
adoção das fórmulas há tanto utilizadas no processo civil, falando-se apenas em sentença que julga procedente o pedido e sentença que julga improcedente o pedido. Além de mais técnicas, uma vez que não deixam dúvidas de que o que está sub judice não é o acusado, mas o pedido

formulado pela acusação, se mostra livre do simbolismo de base inquisitorial, tão forte nas expressões sentença condenatória e sentença absolutória.

\section{REFERÊNCIAS}

AGOSTINHO, Santo. A graça de cristo e o pecado original. 2. ed. v. 1. Trad. Augustinho Belmonte. São Paulo: Paulus, 1998.

BARROS, Flaviane Magalhães de. (Re)Forma do processo penal: comentários críticos dos artigos modificados pelas Leis n. 11.690/08 e 11.719/08. Belo Horizonte: Del Rey, 2008.

BITTENCOURT, Cezar Roberto. Tratado de Direito Penal. v. 1. 13. ed. São Paulo: Saraiva, 2008.

BITTENCOURT, Guida Fernanda Proença. Sentença penal condenatória como materialidade linguístico-histórica de relações de poder. Anais do X Encontro do Círculo de Estudos Linguísticos do Sul. Cascavel: UNOESTE, 2012.

BORGES, Marcos A

fonso. Comentários ao Código de Processo Civil. v. 2. São Paulo: EUD, 1975.

BORGES, Fernanda Gomes e Souza. A prova no processo civil democrático. Curitiba: Juruá, 2013.

BRASIL. Decreto-lei n. 1.608, de 18 de setembro de 1939. Código de processo civil. Disponível em: <http://www.planalto.gov.br/ccivil_03/decreto-lei/1937-1946/Del1608.htm>. Acesso em 12 set. 2016.

Lei n. 5.869, de 11 de janeiro de 1973. Código de processo civil. Disponível em: <http://www.planalto.gov.br/ccivil_03/leis/L5869.htm>. Acesso em 13 set. 2016.

Lei n. 13.105, de 16 de março de 2015. Código de processo civil. Disponível em: <http://www.planalto.gov.br/ccivil_03/_ato2015-2018/2015/lei/l13105.htm>. Acesso em 13 set.2016.

BRÊTAS, Ronaldo de Carvalho Dias. Processo constitucional e estado democrático de direito. 3. ed. Belo Horizonte: Del Rey, 2015.

CÂMARA. Alexandre Antônio Franco Freitas. Lições de Direito Processual Civil. v. I. 16. ed. Rio de Janeiro: Lumen Juris, 2007. 
CARVALHO, Salo de. Antimanual de criminologia. São Paulo: Saraiva, 2013.

CORDERO, Franco. Procedura penale. 2. ed. Milão: Giuffrè, 1993.

CASTRO, Lola Aniyar de. Criminologia da reação social. Trad. Ester Kosovski. Rio de Janeiro: Forense, 1983.

DEL NEGRI, André Luis. Controle de constitucionalidade no processo legislativo: teoria da legitimidade democrática. Belo Horizonte: Fórum, 2008.

FAZZALLARI, Elio. Istituzioni di dirito processuale. 8. ed. Milão: Cedam, 1996.

GIACOMOLLI, Nereu José. O devido processo penal: abordagem conforme a Constituição Federal e o Pacto de São José da Costa Rica. São Paulo: Atlas, 2014.

GIL, Pedro Ortego. Innocentia praesumpta: absoluciones en el Antiguo Régimen. Cuadernos de historia del derecho. Madri: UCM, v. 10, p. 71-125, 2003.

GRECO, Leonardo. Instituições de processo civil: processo de conhecimento. v. 2. 2. ed. Rio de Janeiro: Forense, 2011.

LEAL, Rosemiro Pereira. Teoria processual da decisão jurídica. São Paulo: Landy, 2002.

Teoria geral do processo: primeiros estudos. 11. ed. Rio de Janeiro: Forense, 2012.

A teoria neoinstitucionalista do processo: uma trajetória conjectural. Belo Horizonte: Arraes, 2013.

LOPES JR, Aury Celso Lima. Introdução crítica ao processo penal (fundamentos da instrumentalidade garantista). 2.ed. Rio de Janeiro: Lumen Juris, 2005.

MARQUES, Leonardo Augusto Marinho. O princípio da oralidade e a descentralização da informação relevante no processo penal. Revista de estudos criminais. São Paulo: IOB, ano X, n. 46, p.157-170, jul/set. 2012.

POPPER, Karl Raimund. A lógica da pesquisa científica. 14. ed. São Paulo: Cultrix, 2009.

PRADO, Geraldo Mascarenhas. Campo jurídico e capital científico: o acordo sobre a pena e o modelo acusatório no Brasil - a transformação de um conceito. In: PRADO, Geraldo; MARTINS, Rui Cunha; CARVALHO, Luís Gustavo Grandinetti Castanho de. (org). Decisão judicial: a 
cultura jurídica brasileira na transição para a democracia. p. 11- 70. São Paulo: Marcial Pons, 2012.

MORAES, Maurício Zanoide de. Presunção de inocência no processo penal brasileiro: análise de sua estrutura normativa para a elaboração legislativa e para a decisão judicial. Rio de Janeiro: Lumen Juris, 2010.

RANGEL, Paulo. Direito processual penal. 20. ed. São Paulo: Atlas, 2012.

SAMPAIO, Denis. A verdade no processo penal: a permanência do sistema inquisitorial através do discurso sobre a verdade real. Rio de Janeiro: Lumen Juris, 2010.

SANTOS, Moacyr Amaral. Primeiras linhas de direito processual civil. v. 1. 23. ed. São Paulo: Saraiva, 2004.

SIQUEIRA, Galdino. Curso de processo criminal: com referencia especial á legislação brazileira. 2. ed. São Paulo: Liv. Magalhães, 1910.

VATICANO. Catecismo da Igreja Católica. São Paulo: Vozes e Loyola, 1993. 